Tersedia online di: http://ejournal-balitbang.kkp.go.id/index.php/jra

\title{
RESPONS IMUN UDANG WINDU Penaeus monodon TERHADAP VAKSIN dsRNA VP-24 PADA DOSIS BERBEDA
}

\section{Sri Redjeki Hesti Mulyaningrum\#, Andi Parenrengi, Bunga Rante Tampangallo, dan Ike Trismawanti}

Balai Riset Perikanan Budidaya Air Payau dan Penyuluhan Perikanan

(Naskah diterima: 10 November 2017; Revisi final: 12 Februari 2018; Disetujui publikasi: 12 Februari 2018)

\begin{abstract}
ABSTRAK
Peningkatan produksi udang windu Penaeus monodon terus diupayakan, salah satunya dengan peningkatan respons imun udang terhadap infeksi penyakit WSSV. Penelitian ini bertujuan untuk mengetahui respons imun udang terhadap pemberian vaksin dsRNA VP-24 pada berbagai dosis. Konstruksi vaksin dsRNA VP-24 dilakukan menggunakan Megascript kit dengan DNA genom VP-24 sebagai template. Vaksinasi dilakukan dengan metode injeksi pada udang windu yang berukuran rata-rata $15,88 \pm 3,50 \mathrm{~g}$; dosis vaksin yang diujikan adalah $0,02 \mu \mathrm{g} ; 0,2 \mu \mathrm{g} ; 2 \mu \mathrm{g}$; dan sebagai kontrol adalah udang yang tidak diberi vaksin. Penelitian terdiri atas empat perlakuan dosis vaksin dengan masing-masing dua ulangan dan dipelihara selama lima hari. Uji tantang dilakukan selama enam hari dengan menginjeksi virus WSSV dalam saline solution (1:3 v/v). Pengamatan terhadap sintasan udang windu dilakukan setiap hari, sedangkan penghitungan total hemocyte (THC) dan ProPO diamati pada hari I, III, dan VI setelah diinfeksi WSSV. Pada akhir pengujian dilakukan pengambilan jaringan hepatopankreas untuk analisis histopatologi. Analisis data dilakukan secara statistik dengan analisis ragam (ANOVA). Hasil yang diperoleh memperlihatkan bahwa injeksi vaksin dsRNA VP-24 dengan dosis $0,2 \mu \mathrm{g}$ memiliki pengaruh yang signifikan terhadap sintasan dan respons imun udang windu $(\mathrm{P}<0,05)$. Vaksin dsRNA VP-24 dengan dosis $0,2 \mu \mathrm{g}$ mampu memberikan sintasan udang windu P. monodon sebesar $65 \%$ dan meningkatkan respons imun udang dengan THC $\left(1.550 \times 10^{\mathrm{t}} \mathrm{sel} / \mathrm{mL}\right)$ dan ProPO $(0,042$ Abs).
\end{abstract}

\section{KATA KUNCl: $\quad$ dsRNA; VP-24; P. monodon; WSSV; dosis}

ABSTRACT: Response immune of black tiger shrimp Penaeus monodon to dsRNA VP-24 vaccine on different doses. By: Sri Redjeki Hesti Mulyaningrum, Andi Parenrengi, Bunga Rante Tampangallo, and Ike Trismawanti

\begin{abstract}
One of the efforts to increase the production of tiger shrimp Penaeus monodon is increasing the immune response against WSSV disease. This study aims to evaluate shrimp immune response to dsRNA VP-24 vaccination at various doses. The construction of dsRNA VP-24 vaccine was performed using M egascript kit with the VP-24 DNA genome as a template. The vaccination was done by injection method on shrimp sized $15.88 \pm 3.50 \mathrm{~g}$. The tested vaccine doses (treatments) were $0.02 \frac{1}{1} \mathrm{~g} ; 0.2 \frac{11}{4} \mathrm{~g} ; 2 \frac{1}{1 / 4} \mathrm{~g}$; and unvaccinated shrimp as the control. The study consisted of four treatments of vaccine doses with two replicates for each treatment. The challenge test was performed by injecting the WSSV virus in salinesolution $(1: 3 \mathrm{v} / \mathrm{v})$. The observation on shrimp survival rate was done daily, while the total hemocyte count (THC) and ProPO observation were performed on the 1st day, 3rd day, and 6th day after WSSV infection. At the end of the experiment, samplings of hepatopancreas for analysis were performed. Data were statistically analyzed using ANOVA. The present study indicated that the injection of $0.2^{1 / 4} \mathrm{~g}$ dsRNA VP-24 vaccine had a significant effect on the survival rate and immune response of shrimp $(P<0.05)$. The dose of $0.2 \frac{1}{4} \mathrm{~g}$ dsRNA VP-24 had resulted in $65 \%$ of survival rate and increased immune response of P. monodon with THC (1,550 x 10t cell/mL) and ProPO (0.042 Abs).
\end{abstract}

KEYWORDS: $\quad$ dsRNA; VP-24; P. monodon; WSSV; dose

\footnotetext{
\# Korespondensi: Balai Riset Perikanan Budidaya Air Payau dan Penyuluhan Perikanan. Jl. Makmur Dg. Sitakka No.129, Maros 90512, Sulawesi Selatan, Indonesia.

Tel. + 62411371544

E-mail: mulyaningrum@kkp.go.id
} 


\section{PENDAHULUAN}

Udang merupakan salah satu sumberdaya perikanan yang bernilai ekonomis tinggi yang banyak dibudidayakan terutama udang vaname Litopenaeus vannamei dan udang windu P. monodon (Tassanakajon et al., 2013). Kemampuan replikasi yang cepat dan virulensi patogen yang ekstrem menjadikan WSSV sebagai isu global. Invertebrata seperti udang tidak memiliki limfosit dan antibodi fungsional (imunoglobulin) dan karenanya sistem kekebalan tubuh udang dikenal sebagai sistem kekebalan 'non-spesifik' atau 'bawaan'. Pada arthropoda, udang merupakan satu di antara spesiesnya, mengandalkan sistem kekebalan bawaan, yang terdiri atas sistem kekebalan humoral dan seluler terhadap infeksi virus (Li \& Xiang, 2013). Pada invertebrata, vaksin berfungsi sebagai stimulan kekebalan tubuh non-spesifik (Rowley \& Pope, 2012).

Virus WSSV merupakan virus double-stranded DNA (dsDNA) terbentuk dari makromolekul kompleks yang secara spesifik melekat dan disusun untuk perlindungan dan transfer genom virus. Gen-gen WSSV yang ditranskripsikan pada fase lanjut (late phase) meliputi gen-gen yang menyandi protein struktural utama WSSV yaitu VP-28, VP-26, VP-24, VP-19, dan VP-15. Viral protein ini berpeluang untuk dijadikan sebagai vaksin rekombinan (Sánchez-Paz, 2010). Teknologi interferensi RNA (RNAi) merupakan teknik vaksinasi DNA rekombinan yang spesifik dan efektif untuk menghambat replikasi virus dengan introduksi small interference (si)RNA maupun double-stranded (ds)RNA pada target gen virus (Haq et al., 2012; Jayachandran et al., 2012; Thammasorn et al., 2015). Teknologi vaksinasi menggunakan agen virus dsRNA berkembang sangat pesat terutama dibidang medis, pertanian, dan akuakultur (Jin et al., 2010; Lichner et al., 2003; Rowley \& Pope, 2012). Di bidang akuakultur, teknologi ini banyak dikembangkan untuk menanggulangi penyakit yang disebabkan oleh virus pada udang (Mejía-Ruíz et al., 2011; Ahanger et al., 2014). Beberapa penelitian vaksinasi udang menggunakan agen WSSV sebagai sumber vaksin telah menunjukkan kemajuan dan memperoleh hasil yang menggembirakan (Huang et al., 2014; Kumar et al., 2015; Puneeth et al., 2017).

Isolasi dan karakterisasi gen virulen WSSV VP-24, telah berhasil dilakukan (Tenriulo et al., 2015), namun pemanfaatannya sebagai vaksin dsRNA untuk meningkatkan respons imun udang windu masih memerlukan kajian yang lebih lanjut. Penelitian ini bertujuan untuk mengetahui respons imun udang windu Penaeus monodon terhadap pemberian vaksin dsRNA VP-24 dengan dosis yang berbeda secara in vitro.

\section{BAHAN DAN METODE}

\section{Persiapan Vaksin dsRNA VP-24}

Tahapan dalam konstruksi vaksin dsRNA VP-24 sesuai prosedur Megascript RNAi Kit meliputi: persiapan template DNA, produksi dsRNA, nuclease digestion, dan purifikasi.

\section{Persiapan Template DNA}

Cetakan DNA (template) dikonstruksi dari DNA genom VP-24 yang telah diisolasi dari udang windu dengan teknik PCR. Isolasi menggunakan primer T7 VP-24 (Sarathi et al., 2010) : VP-24 forward : 5'-TA ATA CGA CTC ACT ATA GGG AGA CGC GGA TCC GAT GCA CAT GTG GGG GGT TTA C-3'. VP-24 reverse : 5'-TA ATA CGA CTC ACT ATA GGG AGA CCG GAA TTC TTA TTT TTC CCC AAC CTT AAA CAG-3'.

Amplifikasi fragmen DNA dilakukan pada thermacycler (GeneAmp PCR System 2700, Applied Biosystem) dengan suhu annealing $72^{\circ} \mathrm{C}$ menggunakan kit PureTaq Ready-To-Go PCR Beads (GE Healthcare). Sebanyak $1 \mu \mathrm{L}$ genom VP-24 sebagai template direaksikan dengan primer mix (primer T7 VP-24 reverse dan forward masing-masing $1 \mu \mathrm{L}$ ) dan $\mathrm{dH} 2 \mathrm{O}$ hingga volume total $25 \mu \mathrm{L}$., amplikon selanjutnya dipisahkan dengan menggunakan teknik elektroforesis menggunakan marker 100 bp pada gel agarose $2 \%$ pada tegangan 50 volt selama dua jam. Amplikon yang diperoleh kemudian digunakan sebagai bahan untuk memproduksi vaksin dsRNA.

\section{Produksi dsRNA}

Amplikon sebanyak 1-2 $\mu \mathrm{g}$ direaksikan dengan ATP, CTP, GTP, UTP, 10x T7 reaction buffer $\left(37^{\circ} \mathrm{C}\right)$, T7 enzyme mix, dan nuclease free water sesuai prosedur Megascript RNAi Kit. Larutan yang diperoleh diinkubasi pada $37^{\circ} \mathrm{C}$ selama enam jam, kemudian dilanjutkan dengan inkubasi pada $75^{\circ} \mathrm{C}$ selama lima menit. dsRNA yang diperoleh kemudian didiamkan pada suhu kamar selama 3-4 jam, selanjutnya disimpan pada suhu $-20^{\circ} \mathrm{C}$ atau $-80^{\circ} \mathrm{C}$.

\section{Nuclease Digestion}

Sebanyak $20 \mu \mathrm{L}$ dsRNA yang dihasilkan direaksikan dengan nuclease free water, 10x digestion buffer, DNase, dan RNase. Larutan diinkubasi pada suhu $37^{\circ} \mathrm{C}$ selama satu jam dan dsRNA yang dihasilkan kemudian dipurifikasi.

\section{Purifikasi dsRNA}

Purifikasi dsRNA dilakukan dengan mereaksikan $50 \mu \mathrm{L}$ dsRNA dengan nuclease free water, 10x binding buffer, dan etanol 100\% Kemudian dilakukan 
sentrifugasi, untuk memisahkan supernatan dan homogenat. Homogenat yang diperoleh dicuci dengan wash solution dan disentrifuge, homogenat yang diperoleh kemudian diberi elution solution $\left(95^{\circ} \mathrm{C}\right)$ dan disentrifuge kembali. Supernatan yang diperoleh merupakan dsRNA murni sebagai bahan vaksin. Hasil dsRNA yang diperoleh merupakan bahan vaksin dsRNA VP-24 yang akan diaplikasikan pada hewan uji.

\section{Vaksinasi Udang Windu dengan Vaksin dsRNA VP-24}

Vaksinasi dilakukan dengan metode injeksi intramuskular pada udang windu berukuran rata-rata $(15,88 \pm 3,50 \mathrm{~g})$ dan panjang rata-rata $(11,91 \pm 1,11$ $\mathrm{cm})$. Dosis vaksin yang diujikan merujuk pada penelitian Loy et al. (2012) yakni: 0,02 $\mu \mathrm{g} /$ ekor; 0,2 $\mu \mathrm{g} / \mathrm{ekor}$; dan $2 \mu \mathrm{g} / \mathrm{ekor}$ dan udang yang diinjeksi dengan salinesolution (SS) tanpa vaksin sebagai kontrol. Udang yang telah divaksin dipelihara pada bak terkontrol yang berukuran $80 \mathrm{~cm} \times 80 \mathrm{~cm} \times 60 \mathrm{~cm}$ yang dilengkapi dengan aerasi, dengan kepadatan 10 ekor/bak sebanyak tiga ulangan. Pemeliharaan dilakukan selama lima hari, kemudian dilakukan pengukuran THC dan proPO sebagai data awal sebelum dilakukan uji tantang.

\section{Pengujian Respons Imun Udang Windu}

Uji tantang dilakukan lima hari setelah injeksi vaksin dsRNA VP-24, pengujian dilakukan pada delapan buah bak terkontrol berukuran $80 \mathrm{~cm}$ x $80 \mathrm{~cm} \times 60$ $\mathrm{cm}$ yang dilengkapi dengan aerasi. Setiap bak diisi dengan 10 ekor udang windu yang telah diberi perlakuan dosis vaksin dengan dua ulangan untuk setiap perlakuan. Udang windu yang telah divaksin dengan dosis sesuai perlakuan kemudian diinjeksi dengan virus WSSV yang telah dikonfirmasi patogenitasnya. Virus WSSV diperoleh dari hemolim udang windu yang terinfeksi WSSV. Hemolim kemudian disentrifuge pada $3.000 \mathrm{~g}$ selama 20 menit pada suhu $4^{\circ} \mathrm{C}$. Supernatan yang diperoleh diambil dan disentrifuge kembali pada $8.000 \mathrm{~g}$ selama 30 menit pada suhu $4^{\circ} \mathrm{C}$. Supernatan kemudian difilter dengan menggunakan cellulose nitrate membrane filter $0,2 \mu \mathrm{m}$. Hasil yang diperoleh disimpan dalam biofreezer $\left(-80^{\circ} \mathrm{C}\right)$ sebagai stok virus WSSV. Stok WSSV kemudian diencerkan dengan SS perbandingan 1:3 (v/v) dan diinjeksikan ke udang dengan volume $100 \mu \mathrm{L} / \mathrm{ekor}$.

Pengamatan terhadap udang yang telah diinfeksi WSSV dilakukan selama enam hari. Sintasan udang diamati setiap hari, sedangkan pengamatan terhadap THC dan proPO dilakukan pada awal sebelum injeksi WSSV, hari ke-1, 3, dan 6. Pengamatan proPO didasarkan pada pengukuran absorbansi menggunakan L-DOPA sebagai substrat. Hemolim udang diberi antikoagulan Trisodium citrate $3,8 \%$ kemudian disentrifuge pada suhu $4^{\circ} \mathrm{C}$ dengan kecepatan $1.000 \mathrm{rpm}$ selama 20 menit. Homogenat yang diperoleh dilarutkan dengan cocodylate citrate buffer dan disentrifuge, prosedur ini diulang hingga dua kali dan homogenat yang diperoleh dibagi dua. Satu sampel homogenat digunakan untuk pengukuran tripsin dan satu sampel yang lain untuk pengukuran LDOPA. Masing-masing sampel diukur absorbansinya pada spektra $490 \mathrm{~nm}$. Pada akhir pengujian dengan WSSV, dilakukan pengambilan sampel hepatopankreas untuk analisis histopatologi.

Penelitian dirancang dengan rancangan acak lengkap (RAL) menggunakan analisis ragam (ANOVA), dengan empat perlakuan dan dua ulangan untuk masing-masing perlakuan dosis vaksin. Data histologi dianalisis secara deskriptif.

\section{HASIL DAN BAHASAN}

\section{Sintasan Udang Windu}

Pengamatan terhadap sintasan udang windu selama uji tantang memperlihatkan pemberian vaksin VP-24 dengan dosis $0,2 \mu \mathrm{g}$ mampu meningkatkan sintasan udang sebesar 65\%dibandingkan kontrol (10\% (Gambar 1). Hasil analisis ragam (ANOVA) menunjukkan bahwa pemberian vaksin dsRNA VP-24 memberikan pengaruh yang signifikan terhadap sintasan udang $(P<0,05)$.

Penelitian terdahulu oleh Krishnan et al. (2009) melaporkan bahwakonstruksi vaksin DNA rekombinan mampu memproteksi udang windu hingga 62\% terhadap serangan WSSV. Sarathi et al. (2010) memperoleh mortalitas komulatif udang windu $P$. monodon sebesar 37\% dengan injeksi dsRNA VP-24. Sintasan yang diperoleh pada penelitian ini lebih tinggi dari hasil yang diperoleh oleh Puneeth et al. (2017) yang memperoleh sintasan udang windu sebesar $50 \%$ dengan injeksi vaksin VP-24 in vivo dengan dosis 2,5 $\mu \mathrm{g} / \mathrm{g}$ bobot udang.

Fungsi VP-24 pada siklus hidup WSSV belum banyak diketahui, VP-24 terbukti tidak dapat mengikat membran sel inang. Hasil penelitian terdahulu membuktikan adanya interaksi langsung VP-24 dan VP28 masing-masing membentuk kompleks protein dan berpartisipasi dalam infeksi virus secara bersamasama. Menurut Chen et al. (2007), gen penyandi VP24 memiliki peran sebagai penghubung protein struktural dari protein VP-28, VP-26, WSV-10, dan protein lain untuk membentuk ikatan kompleks pada amplop virus. Anti-VP-24 IgG dapat mencegah serangan WSSV secara signifikan (Xie \& Yang, 2006).

Gen VP-24 memiliki homologi yang tinggi dengan sekuens protein-protein histon sehingga protein ini 


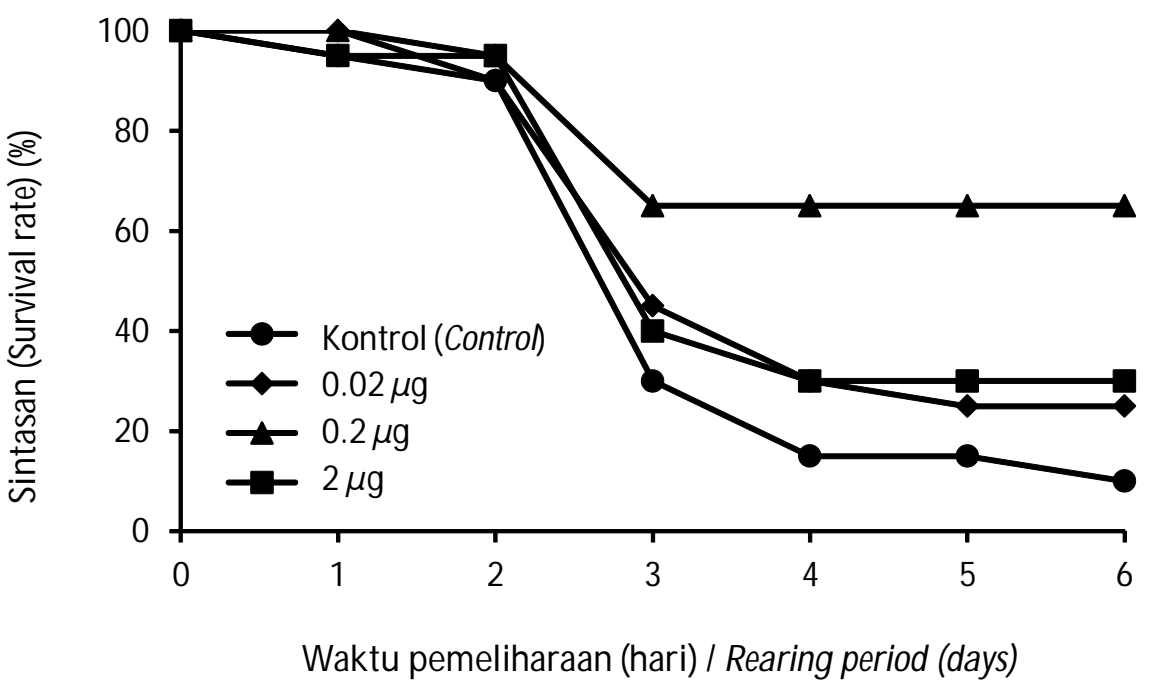

Gambar 1. Sintasan udang windu pada aplikasi vaksin dsRNA VP-24 secara in vitro.

Figure 1. Survival rate of P. monodon on in vitro dsRNA VP-24 vaccine application.

diperkirakan memiliki peran dalam pengikat DNA WSSV, membentuk poros nukleoprotein (nucleoprotein core) dan berperan dalam infeksi sistemik pada udang, dan dapat menstimulasi munculnya sistem kekebalan padaudang windu (Underwood et al., 2013).

Pada hewan akuatik terutama krustasea, mekanisme intereferensi RNA terjadi pada beberapa tahap, pada saat dsRNA diinduksi ke dalam sel target terlebih dahulu terjadi pembentukan siRNA yang kemudian mendegradasi mRNA sehingga ekspresi gen secara spesifik menjadi inaktif pada tahap posttranskripsi (Reshi et al., 2014; He et al., 2015).

\section{Total Hemocyte Count (THC)}

Hasil penghitungan total hemosit (THC) nampak terjadi adanya peningkatan pada udang windu yang diberi vaksin dsRNA VP-24 (Gambar 2).

Jumlah hemosit tertinggi diperoleh pada pemberian vaksin sebesar $0,2 \mu \mathrm{g}\left(1.550 \times 10^{\mathrm{t}} \mathrm{sel} / \mathrm{mL}\right)$ dan terendah pada kontrol $\left(490 \times 10^{\mathrm{t}} \mathrm{sel} / \mathrm{mL}\right)$. Pemberian vaksin dsRNA VP-24 terhadap udang windu memberikan pengaruh yang signifikan terhadap penghitungan jumlah hemosit, THC $(P<0,05)$. Pada kontrol terjadi penurunan THC setelah dilakukan uji tantang (Gambar 3). Menurut Yeh et al. (2009), terjadinya penurunan THC pasca uji tantang disebabkan oleh bermigrasinya sel hemosit dari sistem sirkulasi tubuh menuju jaringan, dengan banyaknya sel yang terinfeksi. Infeksi WSSV yang berada pada fase kritis menyebabkan terjadinya reaksi sel-sel hemosit untuk melakukan berbagai mekanisme pertahanan tubuh yang terdiri atas proses pengenalan patogen, fagositosis, melanisasi, dan sitotoksisitas. Pada pemberian vaksin dengan dosis $2 \mu \mathrm{g}$ juga terjadi penurunan jumlah THC, menurut Harikrishnan et al. (2011) pemberian imunostimulan melebihi dosis optimal dapat menyebabkan imunosupresi pada udang uji, tetapi dapat memproteksi ikan/udang terhadap serangan penyakit. Efektor utama sel-sel sistem kekebalan tubuh pada krustasea adalah hemosit, sementara hepatopankreas bertanggung jawab untuk biosintesis dari beberapa faktor humoral. Peningkatan sel-sel hemosit dalam tubuh udang berperan penting dalam menghambat atau menghancurkan patogen yang masuk ke dalam tubuh udang. Pada udang, seperti dalam krustasea lainnya, terdapat tiga jenis utama hemosit (sel darah) yakni sel hialin, sel semi-granular dan sel granular (granulosit), yang semuanya berperan dalam kekebalan tubuh dan pertahanan terhadap infeksi penyakit. Pemberian imunostimulan yang dilakukan secara terus-menerus dapat mengatur dan mempertahankan sistem imun pada kondisi optimal sampai dengan pemberian berhenti dilakukan (Cerenius et al., 2010; Rowley \& Pope, 2014; Jane et al., 2015).

\section{Aktivitas Prophenoloxydase (proPO)}

Pengamatan pada aktivitas proPO sebelum dan sesudah uji tantang dengan WSSV memperlihatkan bahwa ProPO tertinggi diperoleh pada pemberian vaksin dsRNA VP-24 dengan dosis $0,2 \mu \mathrm{g}(0,042 \mathrm{Abs})$ dan terendah pada dosis $0,02 \mu \mathrm{g}(0,012 \mathrm{Abs})$ seperti disajikan pada Gambar 3. 


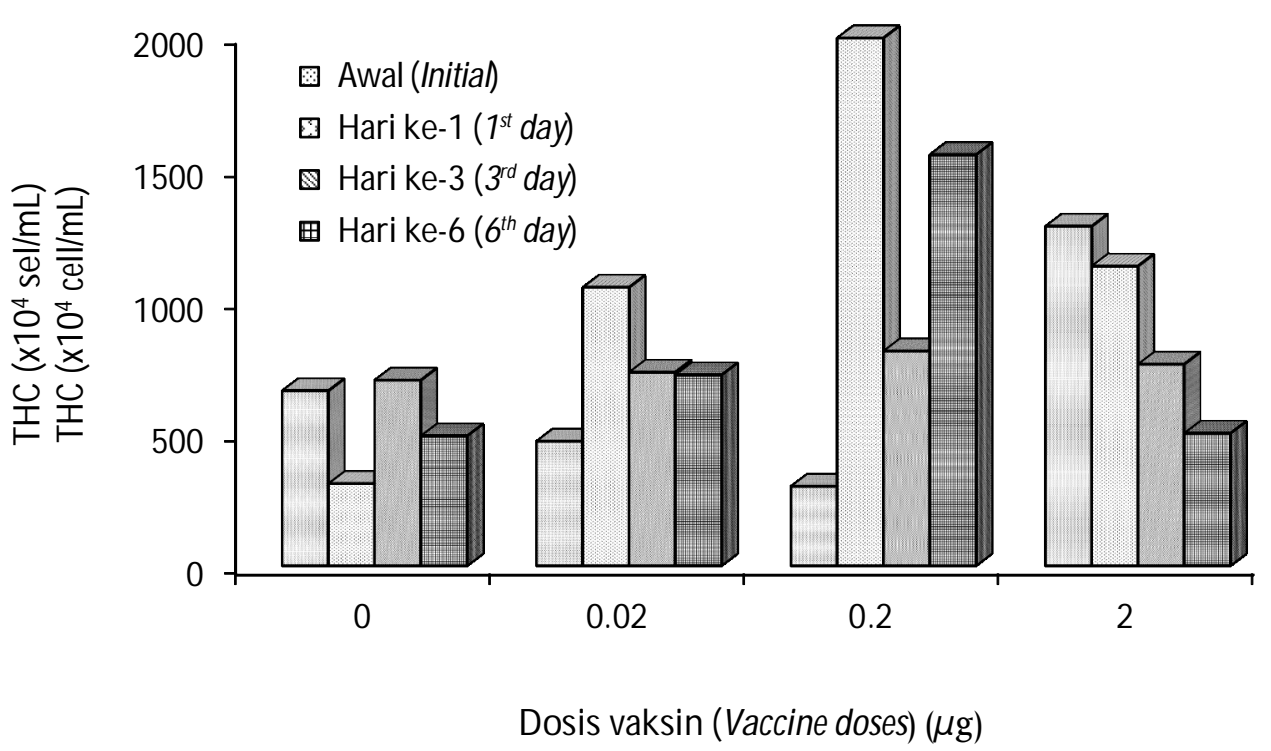

Gambar 2. Jumlah hemosit udang windu pada aplikasi vaksin dsRNA VP-24 dengan dosis berbeda.

Figure 2. Total hemocyte count of black tiger shrimp P. monodon tested with dsRNA VP24 vaccine application with diffenrent doses.

Hasil analisis ragam (ANOVA) memperlihatkan bahwa perlakuan dosis vaksin memberikan pengaruh yang nyata pada aktivitas proPO $(\mathrm{P}<0,05)$. Aktivitas ProPO meningkat pada 24 jam hingga 72 jam setelah diinjeksi. Paria et al. (2013) memperoleh hasil uji tantang WSSV pada pengujian dsRNA VP-28 pada udang windu tidak memberikan perubahan yang signifikan pada ekspresi gen proPO hingga 24 jam, namun terjadi peningkatan ekspresi hingga tiga kali lipat pada 48 jam setelah injeksi.
ProPO merupakan komponen mayor pada sistem imunitas 'innate' pada udang. Sistem kekebalan nonspesifik seluler memiliki dua komponen utama yakni sistem humoral dan seluler, keduanya bekerja secara bersama-sama dan diaktifkan pada saat terjadi tantangan kekebalan. Komponen seluler dimediasi oleh hemosit sedangkan humoral melibatkan komponen yang bebas dari sel hemolymph. Keduanya bersifat interaktif dan saling terkait yang berfungsi secara sinergis untuk melindungi udang dan

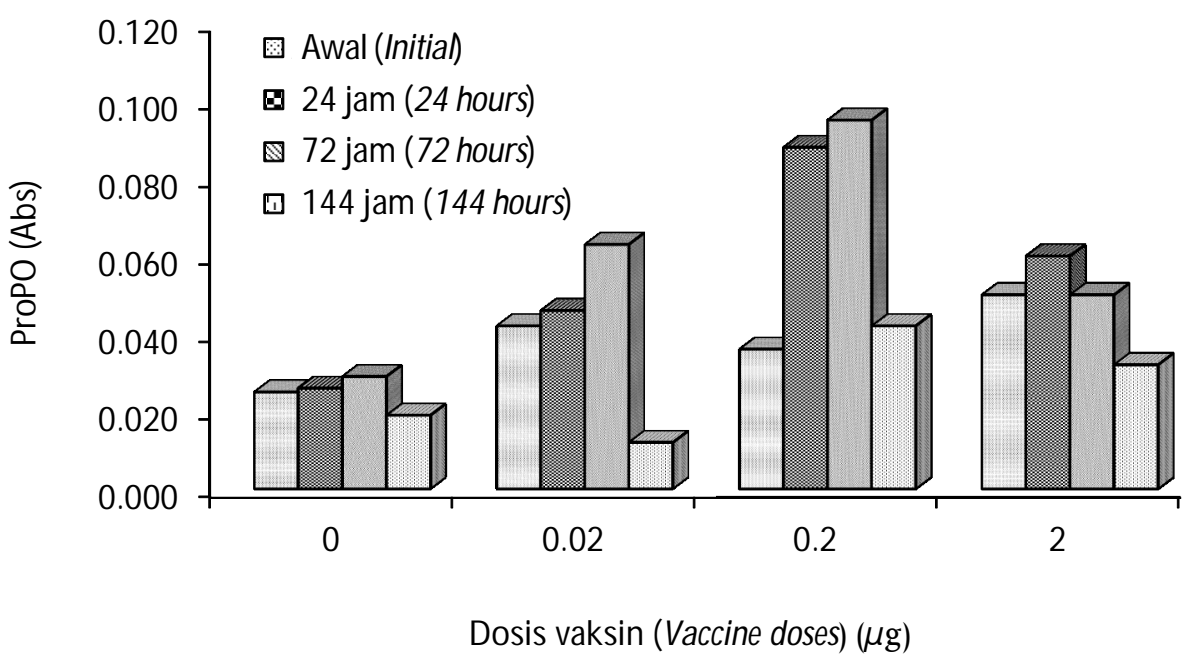

Gambar 3. Aktivitas proPO udang windu P. monodon dengan aplikasi vaksin pada dosis yang berbeda setelah diuji tantang dengan WSSV.

Figure 3. ProPO activity of black tiger shrimp P. monodon tested with different doses of vaccine application after WSSV challenge. 
menghilangkan partikel asing dan patogen. Di antara berbagai jenis respons kekebalan humoral, salah satu teknik imun invertebrata yang paling efektif melawan partikel asing adalah enkapsulasi melanotik seluler. Melanisasi merupakan komponen pertahanan imun pada krustasea di mana sintesis melanin dilakukan dengan mengaktivasi sistem proPO yang melibatkan enzim PO (Tassanakajon et al., 2013). Rangkaian melanisasi kompleks memerlukan kombinasi peredaran hemositina dan beberapa protein yang terkait dengan sistem pengaktifan prophenoloxidase (proPO). Sistem ini merupakan salah satu unsur humoral yang sering berhasil untuk mengatasi penyakit pada invertebrata. Penurunan aktivitas sistem proPO dapat menyebabkan kegagalan fagositosis dan menyebabkan kerusakan jaringan (Amparyup et al., 2013).

Hasil analisis histopatologi pada hepatopankreas udang yang terserang WSSV memperlihatkan adanya beberapa tingkat kerusakan sel hepato pankreas seperti inklusi badan, nekrotik sel, peningkatan degenerasi lemak, dan lisis sel (Gambar 4). Pada Gambar 4a terlihat adanya hipertropi pada inti sel (Cowdry type-
A) tipe inklusi yang merupakan tahap awal infeksi virus WSSV. Tahap tiga infeksi terlihat pada Gambar 4b, di mana inti membran terganggu dan zona pembatas menjadi transparan, dan pada Gambar 4c terlihat sel yang terinfeksi rusak dan mengalami lisis yang merupakan tahap akhir infeksi WSSV.

Menurut Escobedo-Bonilla et al. (2008), pada tahap awal terinfeksi virus WSSV, sel menunjukkan inti sedikit hipertrofi. Dalam sitoplasma, retikulum endoplasma (RE) menjadi membesar dengan berlimpah ribosom bebas. Pada tahap-2; dalam inti, material fibril menginduksi pembentukan membran yang segera diisi dengan materi inti virus membentuk ikatan viral. Pada tahap ini, Cowdry-A jenis inklusi muncul sebagai zona transparan antara virogenic stroma dan sangat padat elektron berbatas kromatin. Inti menjadi hipertrofi dan bulat. Tahap-3 pada inti; nukleokapsid muncul dengan kerapatan elektron rendah dan secara bertahap tumbuh dari satu ujung ke arah yang lain, masih terbuka. Pusat inklusi intranuklear muncul lebih kecil dari dalam sel dan lebih padat elektron karena kehadiran partikel virus yang berlimpah. Ketika kromatin menghilang, inti membran terganggu, dan
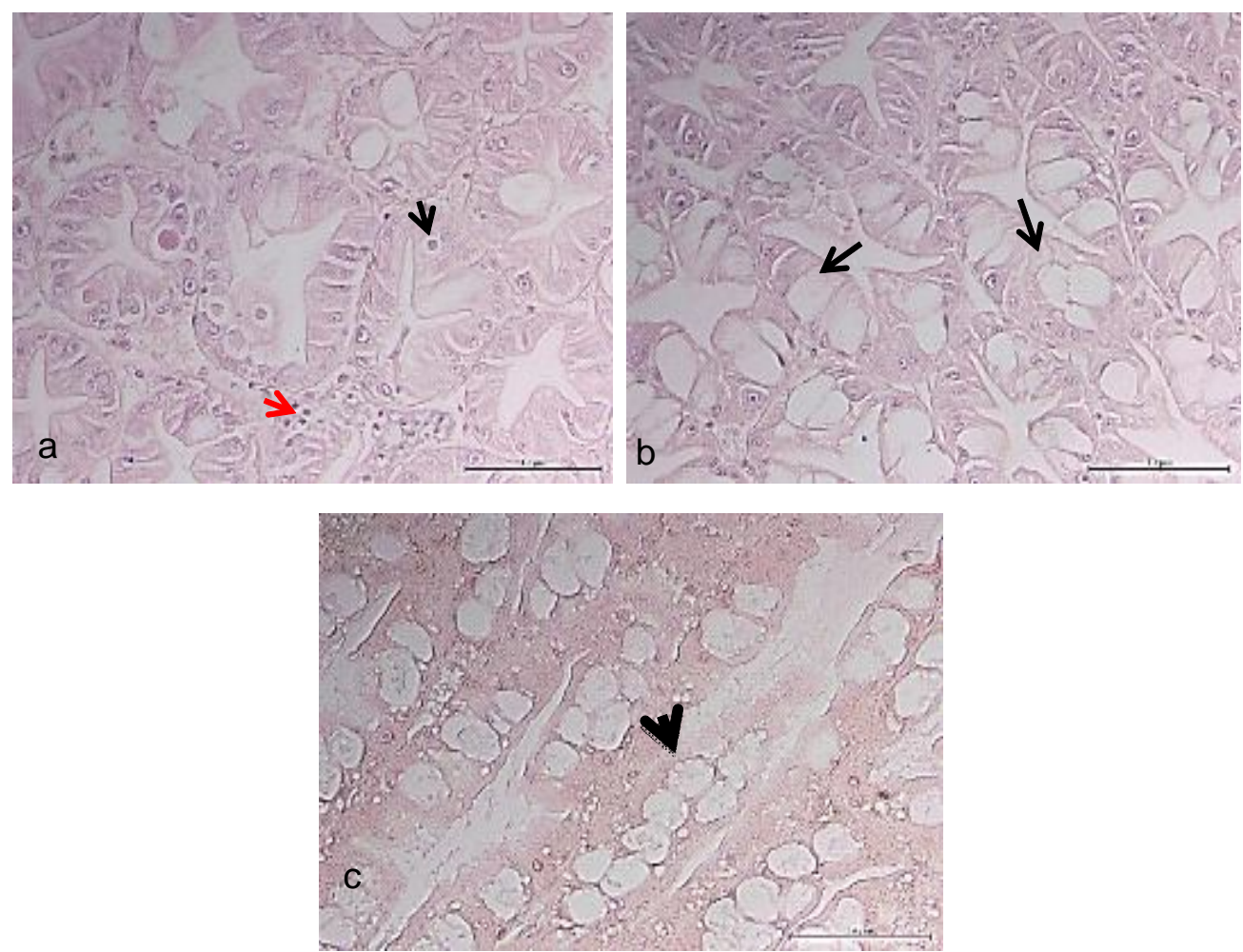

Gambar 4. Profil kerusakan sel hepatopankreas pada udang windu (skala bar $=10 \mu \mathrm{m}$ ): (a) badan inklusi (hitam) dan nekrotik sel (merah); (b) peningkatan degenerasi lemak; dan (c) lisis sel dan degenerasi lemak.

Figure 4. Profile of hepatopancreas cells damage on black tiger shrimp P. monodon (scale bar= $10 \mu \mathrm{m})$ : (a) inclution bodies (black arrow) and necrotic cells (red arrow); (b) increased degeneration of fat (black arrows), and (c) cell lysis and fat degeneration (black arrow). 
zona pembatas menjadi transparan menyatu dengan sitoplasma. Tahap-4 dalam inti, nukleokapsid menjadi benar-benar tertutup oleh amplop virus. Tahap-5 merupakan tahap akhir morfogenesis virus. Pada tahap akhir ini, sel yang terinfeksi rusak parah dan terganggu, ruang void pada jaringan teramati sebagai sel hancur.

Hingga saat ini persoalan penyakit udang yang disebabkan oleh virus WSSV belum dapat diatasi secara efektif. Pemahaman mengenai interaksi molekuler virus patogen WSSV dengan inang dapat memberikan kontribusi untuk mengatasi persoalan penyakit WSSV pada udang (Verbruggen et al., 2016). Produksi vaksin dsRNA merupakan salah satu upaya untuk mengatasi persoalan WSSV yang didasarkan pada pemahaman interaksi molekuler virus dengan inang. Dari hasil penelitian ini diharapkan dapat memberikan implikasi pada peningkatan produksi udang windu P. monodon khususnya di Indonesia melalui pencegahan penyakit WSSV.

\section{KESIMPULAN}

Hasil penelitian menunjukkan bahwa dosis vaksin dsRNA VP-24 sebesar $0,2 \mu \mathrm{g}$ memiliki pengaruh yang signifikan terhadap sintasan $(65 \%$, meningkatkan jumlah hemosit $\left(1.550 \times 10^{4} \mathrm{sel} / \mathrm{mL}\right)$ dan respons imun udang windu yang diindikasikan dari aktivitas ProPO $(0,042 \mathrm{Abs})$.

\section{UCAPAN TERIMA KASIH}

Penelitian ini dibiaya oleh APBN Tahun Anggaran 2017 Balai Riset Perikanan Budidaya Air Payau dan Penyuluhan Perikanan. Ucapan terima kasih disampaikan kepada Ibu Andi Tenriulo, M.Si. yang telah banyak berkontribusi dalam pelaksanaan penelitian, Drh. Wahyuni dalam analisis histopatologi, serta teknisi litkayasa dan nonlitkayasa yang membantu penelitian ini.

\section{DAFTAR ACUAN}

Ahanger, S., Sandaka, S., Ananad, D., Mani, M.K., Kondadhasula, R., Reddy, C.S., Marappan, M., Valappil, R.K., Majumdar, K.C., \& Mishra, R.K. (2014). Protection of shrimp Penaeus monodon from WSSV infection using antisense constructs. Mar. Biotechnol., 16, 63-73.

Amparyup, P., Charoensapsri, W., \& Tassanakajon, A. (2013). Prophenoloxidase system and its role in shrimp immune responses against major pathogens. Fish \& Shellfish Immunology, 34, 990-1001.

Cerenius, L., Jiravanichpaisal, P., Liu, H., \& Söderhäll, I. (2010). Crustacean immunity. In Söderhäll, K. (Ed.), Invertebrate immunity. New York, USA: Landes
Bioscience and Springer Science Business Media, LLC, p. 239-258.

Chen, J., Li, Z., \& Hew, C.L. (2007). Characterization of a novel envelope protein WSV010 of shrimp white spot syndrome virus and its interaction with a major viral structural protein VP24. Virology, 364, 208-213.

Escobedo-Bonilla, C.M., Alday-Sanz, V., Wille, M., Sorgeloos, P., Pensaert, M.B., \& Nauwynck, H.J. (2008). A review on the morphology, molecular characterization, morphogenesis, and pathogenesis of white spot syndrome virus. Journal of Fish Diseases, 31, 1-18.

Haq, MA.B., Vignesh, R., \& Srinivasan, M. (2012). Deep insight into white spot syndrome virus vaccines: A review. Asian Pacific Journal of Tropical Disease, p. 73-77.

Harikrishnan, R., Balasundaram, C., \& Heo, M. (2011). Impact of plant products on innate and adaptive immune system of cultured finfish and shellfish. Aquaculture, 317, 1-15.

He, Y., Jua, C., \& Zhanga, X. (2015). Roles of small RNAs in the immune defense mechanisms of crustaceans. Molecular Immunology, 68, 399-403.

Huang, P.Y., Leu, J.H., \& Chen, L.L. (2014). A newly identified protein complex that mediates white spot syndrome virus infection via chitin-binding protein. Journal of General Virology, 95, 1799-1808.

Jane, M.S., Amar, A., \& Amar, E.C. (2015). Use of immunostimulans in shrimp culture: An update. Biotechnological advances in shrimp health management in the Philippines. Research Signpost, $p$. 45-71.

Jayachandran, B., Hussain, M., \& Asgari, S. (2012). RNA Interference as a cellular defense mechanism against the DNA virus baculovirus. Journal of Virology, 86(24), 13729-13734.

Jin, B., Sun, T., Yu, X.H., Liu, C.Q. Yang, Y.X. Lu, P., Fu, S.F., Qiu, H.B., \& Yeo, A.E.T. (2010). Immunomodulatory effects of dsRNA and its potential as vaccine adjuvant. Review Article. Journal of Biomedicine and Biotechnology, p. 1-17.

Krishnan, P., GireshBabu, P., Saravanan, S., Rajendran, K.V., \& Chaudhari, A. (2009). DNA constructs expresing long-hairpin RNA (IhRNA) protects Penaeus monodon against white spot syndrome virus. Vaccine, 27, 3849-3855.

Kumar, A., Laramore, S., Alexander, P., Allnutt, F.C.T., $\&$ Sayre, R.T. (2015). Double stranded RNA simultaneously targeting four white spot syndrome virus (WSSV) genes provides protection against WSSV in Litopenaeus vannamei. Int. J. Marine Sci. Ocean Technol., 2(2), 5-10. 
Li, F., \& Xiang, J. (2013). Recent advances in researches on the innate immunity of shrimp in China. Dev. Com. Immunol., 39, 11-26.

Lichner, Z., Silhavy, D., \& Burgya' n, J. (2003). Doublestranded RNA-binding proteins could suppress RNA interference-mediated antiviral defences. Journal of General Virology, 84, 975-980.

Loy, J.D., Mogler, M.A., Loy, D.S., Janke, B., Kamrud, K., Scura, E.D., Harris, D.L.H., \& Bartholomay, L.C. (2012). dsRNA provides sequence-dependent protection against infectious myonecrosis virus in Litopenaeus vannamei. Journal of General Virology, 93, 880-888.

Mejía-Ruíz, C.H., Vega-Peña, S., Alvarez-Ruiz, P., \& Escobedo-Bonilla, C.M. (2011). Double-stranded RNA against white spot syndrome virus (WSSV) VP28 or VP26 reduced susceptibility of Litopenaeus vannamei to WSSV, and survivors exhibited decreased susceptibility in subsequent re-infections. Journal of Invertebrate Pathology, 107, 65-68.

Paria, A., Greeshma, S.S., Chaudhari, A., Makesh, M., Purushothaman, C.S., \& Rajendran, K.V. (2013). Nonspecific effect of double-stranded (ds) RNA on prophenoloxidase (proPO) expression in Penaeus monodon. Appl. Biochem. Biotechnol., 169, 281-289.

Puneeth, T.G., Akhila, D.S., Dechamma, M.M., Shreeharsha, J.M., Shivakumar, S.K., \& Venugopal, M.N. (2017). Comparative efficacy of dsRNA VP24, VP26, RR1 and WSV477 gene against WSSV infection in Penaeus monodon. Int. J. Curr. Microbiol. App. Sci., 6(2), 665-674.

Reshi, M.L., Wu, J.L., Wang, H.V., \& Hong, J.R. (2014). RNA interference technology used for the study of aquatic virus infections. Fish \& Shellfish Immunology, 40, 14-23.

Rowley, A.F., \& Pope, E.C. (2012). Vaccines and crustacean aquaculture: A mechanistic exploration. Aquaculture, 334-337, 1-11.

Sánchez-Paz, A. (2010). White spot syndrome virus: an overview on an emergent concern. Vet. Res., 41(43), 34.
Sarathi, M., Simon, M.C., Venkatesan, C., Thomas, J., Ravi, M., Madan, N., Thiyagarajan, S., \& Hameed, A.S.S. (2010). Efficacy of bacterially expressed dsRNA specific to different structural genes of white spot syndrome virus (WSSV) in protection of shrimp from WSSV infection. Journal of Fish Diseases, 33, 603-607.

Thammasorn, T., Sangsuriya, P., Meemetta, W., Senapin, S., Sarocha Jitrakorn, S., Rattanarojpong, T., \& Saksmerprome, V. (2015). Large-scale production and antiviral efficacy of multi-target double-stranded RNA for the prevention of white spot syndrome virus (WSSV) in shrimp. BMC Biotechnology, 15, 110-116.

Tassanakajon, A., Somboonwiwat, K., Supungul, P., \& Tang, S. (2013). Discovery of immune molecules and their crucial functions in shrimp immunity. Fish \& Shellfish Immunology, 34, 954-967.

Tenriulo, A., Tampangallo, B.R., Parenrengi, A., \& Dewi, R.A. (2015). Isolasi dan karakterisasi gen penyandi protein VP-24 WSSV pada udang windu (Penaeus monodon) untuk pengembangan teknologi RNAi. Prosiding Forum Inovasi Teknologi Akuakultur, hlm. 593-598.

Underwood, D.J., CowleyJ.A., \& Johnson, K.N. (2013). Antiviral immunity and protection in penaeid shrimp. Review Article. Versita, Invertebrate Immunity, p. 2-14.

Verbruggen, B., Bickley, L.K., Aerle, R.V., Bateman, K.S., Stentiford, G.D., Santos, E.M., \& Tyler, C.R. (2016). Molecular mechanisms of white spot syndrome virus infection and perspectives on treatments. Viruses, 8(23), 1-29.

Xie, X., \& Yang, F. (2006). White spot syndrome virus VP24 interacts with VP28 and is involved in virus infection. Journal of General Virology, 87, 1903-1908.

Yeh, S.P., Chen, Y.N., Hsieh, S.L., Cheng, W., \& Liu, C.H. (2009). Immune response of white shrimp, Litopenaeus vannamei, after a concurrent infection with white spot syndrome virus and infectious hypodermal and hematopoietic necrosis virus. Fish Shellfish Immun., 26, 582-588. 